\title{
CORRIGENDUM
}

\section{Meta-analysis of the global gene expression profile of triple-negative breast cancer identifies genes for the prognostication and treatment of aggressive breast cancer}

F Al-Ejeh, PT Simpson, JM Saunus, K Klein, M Kalimutho, W Shi, M Miranda, J Kutasovic, A Raghavendra, J Madore, L Reid, L Krause, G Chenevix-Trench, SR Lakhani and KK Khanna

Oncogenesis (2014) 3, e124; doi:10.1038/oncsis.2014.41; published online 27 October 2014

Correction to: Oncogenesis (2014) 3, e100; doi:10.1038/oncsis.2014.14; published online 21 April 2014

Since the publication of the above manuscript the authors have identified an error in the author list; the name of the third author was incorrectly presented. The corrected author list is shown above. 